\section{Studia z Filologii Polskiej i Słowiańskiej}

DOI: $10.11649 /$ sfps.1774
Studia z Filologii Polskiej i Słowiańskiej, 54

Warszawa 2019

Article No. 1774

\section{Citation:}

Кузь, Г.Т. (2019). Лексичні запозичення в діалектній фразеології говірок Чернівецької області: Діахронічний аспект. Studia $z$ Filologii Polskiej i Stowiańskiej, 54. https://doi.org/10.11649 /sfps.1774

Kuz', H. T. (2019). Leksychni zapozychennia v dialektnií frazeolohiï horivok Chernivets'koï oblasti: Diakhronichnyı̌ aspekt. Studia $z$ Filologii Polskiej i Słowiańskiej, 54. https://doi.org/10.11649 /sfps.1774

\author{
Галина Т. Кузь \\ (Чернівецький національний університет \\ імені Юрія Федьковича)
}

\title{
Лексичні запозичення в діалектній фразеології говірок Чернівецької області: діахронічний аспект
}

В останні десятиріччя минулого століття й на початку нинішнього в українському мовознавстві помітно зросла зацікавленість вивченням ареальної фразеології. Вагомим кроком у впорядкуванні буковинської діалектної фразеології став вихід у світ матеріалів до словника Фразеологізми та паремії Чернівеччини (ФПЧ, 2017). «У роботі представлено результати збору матеріалів кількох поколінь студентів, останні десять років було присвячено спеціальному збору фразеологічного матеріалу з території Буковини, вибірці фразеологізмів із художніх творів буковинських письменників, а також численних наукових праць» (ФПЧ, 2017, с. 4).

Одним із актуальних напрямів системного вивчення буковинської діалектної фразеології є дослідження історії її розвитку та динаміки змін, у тому числі в ракурсі міжмовних контактів. Історію розвитку лексики буковинських говорів у ХХ ст. дослідив К. Герман (Герман, 2008), фразеологію західного варіанта літературної мови на матеріалі писемних

This is an Open Access article distributed under the terms of the Creative Commons Attribution 3.0 PL License (creativecommons.org/licenses/by/3.0/pl/), which permits redistribution, commercial and non-commercial, provided that the article is properly cited. (c) The Author(s) 2019.

Publisher: Institute of Slavic Studies, Polish Academy of Sciences

[Wydawca: Instytut Slawistyki Polskiej Akademii Nauk] 
Галина Т. Кузь Лексичні запозичення в діалектній фразеології говірок Чернівецьької області...

джерел кінця XIX - поч. XX ст. з погляду міжмовних контактів вивчала Л. Ткач (Ткач, 2007). Комплексно історія міжмовних контактів на діалектному фразеологічному матеріалі Чернівеччини не досліджувалася, що й визначає актуальність і новизну нашої розвідки.

Мета дослідження - проаналізувати історію міжмовних контактів у діалектній фразеології Чернівеччини в XX - на початку XXI ст. на матеріалі фразеологізмів з іномовними компонентами, з'ясувати особливості фразеологізмів із запозиченнями з мов, з якими мали найбільш тісні взаємні контакти мешканці сучасної Чернівецької області. Об'єктом дослідження є діалектні фразеологічні одиниці (далі - ДФО) Чернівеччини з іномовними компонентами, а предметом вивчення - особливості міжмовної взаємодії на фразеологічному рівні мовної структури.

Матеріалом дослідження слугує вибірка ДФО із запозиченими компонентами, зафіксованими словником Фразеологізми та паремії Чернівеччини. Для ретроспективного аналізу використовуємо праці дослідників міжмовних контактів на лексичному та фразеологічному рівнях мовної системи діалектного мовлення.

Діалектну фразеологію південно-західних говірок з погляду міжмовних контактів досліджували О. Дехтярова (на матеріалі мови творів західноукраїнських письменників) (Дехтярова, 2013); В. Лопушанський, Т. Пиц (іншомовні запозичення через посередництво німецької мови) (Лопушанський \& Пиц, 2011). Загалом запозичення у буковинських говірках були предметом дослідження К. Германа (романські, германські) (Герман, 2008, 2010), Н. Головач (румунськомовні) (Головач, 2012), Н. Нечаєвої (Нечаєва, 2014) та О. Сеник (Сеник, 2014) (німецькомовні).

\section{Румунізми у складі ДФО}

Оскільки буковинські говірки межують із говірками румунської мови, а подекуди носії обох мов проживають поряд в межах одних населених пунктів, інтерферентні процеси в них мають давню історію. Розглянемо вплив румунської мови на компонентний склад ДФО.

У словнику Фразеологізми та паремії Чернівеччини фіксуємо 39 ДФО, що включають 29 лексем-компонентів румунського/молдавського походження:

брати/взяти на габи (гарби) кого. 1. 'брати на плечі когось, наприклад, дитину', 2. ‘брати когось на утримання', Заст., Стор. (ФПЧ, 2017, 
Галина Т. Кузь Лексичні запозичення в діалектній фразеології говірок Чернівецької області...

c. 43). ГАРБИ - з рум. gârbiţă 'горб між шиєю та спиною коня' (PPC, 1922, c. 183);

брати на конт, заст. 'брати в борг'. Кіцм. (ФПЧ, 2017, с. 44). КОНТ з рум. cont 'рахунок, звіт' (РУС, 1996, с. 100); пор. брати на зошит (хрестик) (ФПЧ, 2017, с. 44);

говорити дурної клаки, знев. 'говорити дурниці'. Заст., Кіцм., Вижн., Нов. (ФПЧ, 2017, с. 67); робити клаку. 'спільне виконання сільськогосподарських чи будівельних робіт'. Кіцм., Вижн., Стор. (ФПЧ, 2017, с. 190). КЛАКА - 'гуртова праця у сусіда чи родича', запозичення з молд. мови; молд. клакэ 'панщина; гуртова робота' (ЕСУМ, 1982-2012, т. 2, с. 453);

дати фрики кому. 'посварити'. Вижн. (ФПЧ, 2017, с. 77); збити фрику 3 кого. 'збити гонор з когось, насварити'. Заст. (ФПЧ, 2017, с. 97); мати (знати) фрику. ‘бути слухняним, дисциплінованим'. Кіцм., Вижн., Стор. (ФПЧ, 2017, с. 133); Святилася (світиласи) би фрика, [хоть і невелика]. Кіцм., Вижн., Герц. (ФПЧ, 2017, с. 325); ФРИКА заст. 'насильство, примус'; з рум. freca 'лупцювати' (РУС, 1996, c. 179) або frică 'боязнь, страх' (РУС, 1996, с. 180);

дивитися урсом на кого. 'гніватися на когось, дивитися спідлоба'. Заст., Вижн., Герц., Нов. (ФПЧ, 2017, с. 79). УРСОМ - 'спідлоба'; з рум. urs 'ведмідь' (РУС, 1996, с. 493);

і габар не мати. 'не перейматися'. Вижн., Герц. (ФПЧ, 2017, с. 104). ГАБАР - рум. habar 'турбота, клопіт, журба' (РУС, 1996, с. 199);

i sama. 'крапка, кінець, все’. Пут. (ФПЧ, 2017, с. 104). ГАТА - рум. gată 'кінець' (РУС, 1996, с. 188);

іти за скориею, обр., заст. 'наречений забирає наречену до себе додому'. Хот. (ФПЧ, 2017, с. 106). СКОРЦА (скорець) - 'вузький довгий килим'; запозичення з молд. чи рум. мови; молд. скоариэ 'килим' (ЕСУМ, 1982-2012, т. 5, с. 281);

мати капамінте. 'мати розум’. Кіцм., Черн. (ФПЧ, 2017, с. 131). КАПАМІНТЕ - з рум. сар 'голова', minte 'розум') - 'розум';

мати мінти в голові. 'про дивну людину'. Кіцм. (ФПЧ, 2017, с. 131). MIHTA (з рум. minte 'розум') - 'клепка' (СБГ, 2005, с. 291). Маємо тут цікавий випадок енантеосемії: мати всі клепки в голові 'бути 
Галина Т. Кузь Лексичні запозичення в діалектній фразеології говірок Чернівецьької області...

розумним, розсудливим' (ФСУМ I, 1993, т. 1, с. 372), a із компонентом мінти фразеологізм набув протилежного значення;

мати napmb, заст. 1. 'усталене побажання добра, щастя'. Заст. 2. 'мати добру долю'. Герц. 3. 3 чого. 'добре ведеться; з чогось $є$ добрий прибуток'. Герц., Глиб., Черн. (ФПЧ, 2017, с. 132). ПАРТЬ - 'доля, частина'; - очевидно, результат скорочення запозиченого з рум. слова parte ‘частина, пай, доля' (ЕСУМ, 1982-2012, т. 4, с. 300);

мати фацу. 'бути чесним, справедливим, мати совість'. Заг. (ФПЧ, 2017, с. 132). ФАЦА - з рум. facă 'обличчя'. Вживається у наказовій формі як докір за порушення суспільних правил: Мой, брє, май фащу: нашо збиткуӥсси над жінков (Слобідка Глиб.) (СБГ, 2005, с. 585);

на листу катараму, зі сл. сварити, машкарити та ін. 'дуже сильно, останніми словами'. Стор. (ФПЧ, 2017, с. 141). КАТАРАМА - $з$ рум. cataramă 'пряжка, застібка' (РУС, 1996, с. 71). Можливо, йдеться про пряжку ременя як знаряддя побиття;

наводити курицини. 'прибирати'. Пут. (ФПЧ, 2017, с. 138). КУРИЦИНИ з рум. curăţenie 'чистота, охайність' (РУС, 1996, с. 112);

пускати харамана. 'обманювати когось' Заст., Кіцм., Вижн. (ФПЧ, 2017, с. 186). ХАРАМАН - 'обман, вигадка' (СБГ, 2005, с. 610); з рум. haramin 'злодій, шахрай' (ЕСУМ, 1982-2012, т. 6, с. 187); пор. напустити туману (диму) 'те саме' (ФПЧ, 2017, с. 186);

справляти зузи. 'робити гучну забаву, розвагу'. Стор., Глиб. (ФПЧ, 2017, c. 204). ЗУЗИ - з рум. zuzăi 1) 'жужжати' (про бджіл); 2) 'гудіти' (РРC, 1922, с. 801); пор. жарг. гудіти 'пиячити, весело проводити час' (КСЖЛ, 2003, с. 82);

три міхи і двоє бесаг, зі сл. наговорити. 'нісенітниці'. Пут. (ФПЧ, 2017, с. 211); Гонору повні бесаги, а розуму на мушенку нема. Пут. (ФПЧ, 2017, с. 283). БЕСАГИ, БИСАГИ - з рум. desagă 'торби, з'єднані одним полотнищем, що їх носять перекинутими через плече' (РРС, 1922, с. 76); пор. сім мішків гречаної вовни (наговорити), сім мішків арештантів (наговорити) (ФПЧ, 2017, с. 211);

тримати пізвму. 'тримати зло, ворогувати'. Кіцм. (ФПЧ, 2017, с. 211). ПІЗЬМА - з рум. ріzтӑ 'заздрість, злість, злоба' (РУС, 1996, с. 354); пор., тримати зло (ФПЧ, 2017, с. 211); 
Галина Т. Кузь Лексичні запозичення в діалектній фразеології говірок Чернівецьької області...

удатний як малай на призьбі. 'поганий, ні до чого не здатний'. Заст., Кіцм. (ФПЧ, 2017, с. 214); як малай. 'без смаку, ніякий'. Заст., Вижн., Герц. (ФПЧ, 2017, с. 248). МАЛАЙ - 'випічка з кукурудзяного борошна' (СБГ, 2005, с. 274); з рум. malai 'кукурудзяне борошно' (ЕСУМ, 1982-2012, т. 3, с. 369);

ходити льонтом (льондом). 'нічим не займатися, байдикувати'. Заст., Кіцм., Вижн. (ФПЧ, 2017, с. 219). ЛЬОНТ - з рум. lent 'повільний' (РУC, 1996, c. 267);

ходити малурами (мазуриями). 'волочитися невідомо де, тинятися'. Заст., Кіцм., Вижн., Герц. (ФПЧ, 2017, с. 219). МАГУРА - з рум. măgură 'височина, горб’ (РУС, 1996, с. 284). Очевидно, ДФО побудована за моделлю 'ходити + віддалені необжиті території; пор. ходити псячими стежками 'порушувати моральні засади співжиття'(ФПЧ, 2017, с. 220);

чути шкрум. 'відчувати неспокій'. Кіцм. (ФПЧ, 2017, с. 227); на шккрум, зі сл. згоріти. 'цілком, повністю' (ФПЧ, 2017, с. 146). ШКРУМ - 'запах горілої вовни, шкіри, м’яса' (СБГ, 2005, с. 667); 'нагар у димарі; запах горілого; запах горілої шкіри'; запозичення з рум. мови; рум. scrum 'попіл; нагар' (ЕСУМ, 1982-2012, т. 6, с. 435);

як дурний до бризи (бринзі), зі сл. сміятися, згруб. 'недоречно посміхатися'. Вижн., Нов., Кельм. (ФПЧ, 2017, с. 240); як бочка з бринзою (бриндзов), зі сл. сидіти, ходити. 'бути без життєвої енергії'. Пут. (ФПЧ, 2017, с. 234); Брат братом, а бринза за гроші. Пут., Хот. (ФПЧ, 2017, с. 276); БРИНЗА - 'овечий сир'; запозичення зі східнороманських мов; рум. brînză 'сир, бринза' (ЕСУМ, 1982-2012, т. 1, с. 258);

як мавпа бомбонами (бумбонами), зі сл. перебирати. 'дуже'. Вижн. (ФПЧ, 2017, с. 248). БОМБОНА - з рум. bomboană 'цукерка' (РУC, 1996, c. 57);

як мутул, зі сл. ходити. 'сердитий, надутий'. Глиб. (ФПЧ, 2017, с. 250). МУТУЛ - з рум. тиt 'німий' (РРС, 1922, с. 361);

як саджата, зі сл. побігти, бігти. 'швидко'. Глиб., Хот. (ФПЧ, 2017, с. 262). САДЖАТА - з рум. săgeată 'стріла' (РУС, 1996, с. 409);

як той флютор. 'дурень'. Вижн. (ФПЧ, 2017, с. 263). ФЛЮТОР - заст., рідк., знев. 'дурень' (СБГ, 2005, с. 595); ФЛУТ (флутур) - 'негідник, 
Галина Т. Кузь Лексичні запозичення в діалектній фразеології говірок Чернівецьької області...

шахрай'; семантично видозмінене запозичення з рум. мови; рум. fluture 'метелик' (ЕСУМ, 1982-2012, т. 6, с. 112);

Яка ватра, такий дим, який батько, такий син. Кіцм. (ФПЧ, 2017, с. 344); BATPA - 'багаття, вогнище'; від рум. vatră, що вважається здавна успадкованим з індоєвропейської прамови (ЕСУМ, 1982-2012, т. 1, c. 340);

Де гною лопата, там хліба буката (ФПЧ, 2017, с. 285); У кожній хаті по букаті, [та все не однакі]. Заст., Кіцм., Вижн., Нов. (ФПЧ, 2017, c. 332). БУКАТ (буката) - 'кусок, скибка'; давнє запозичення зі східнороманських мов; рум. bucată 'шматок, скибка, штука' (ЕСУМ, 1982-2012, т. 1, с. 285).

За спостереженнями К. Германа, утвердження лексичних запозиченьрумунізмів пов’язане з: а) часом потрапляння в українську мову: збереглися до наших днів ті запозичення, які є дуже давніми (XIV-XVII ст.), в першу чергу, слова, пов'язані з тваринництвом; б) із семантично-стилістичними характеристиками лексем: утвердилися назви предметів побуту, розмовні лексеми, натомість книжна лексика швидко вийшла з ужитку (Герман, 2008, cc. 14-15).

Аналіз ДФО Чернівеччини із запозиченнями-румунізмами частково підтверджує вищенаведені спостереження: у складі ДФО збереглися давні запозичення (бринза, ватра, буката), назви предметів побуту (бесаги, скориа, катарама), назви продуктів харчування (бринза, бомбона, малай), однак найбільше румунізмів належить до групи абстрактних назв (sama, nарть, niзьма, габар, фрика). Частим $є$ вживання запозичень з румунської мови $з$ оцінною конотацією (блютор - дурень, капамінте - розумний), в ряді ДФО оцінна конотація твориться контекстом використання запозичення (удатний як малай на призвбі; як мавпа бомбонами (перебирати); говорити дурної клаки).

Аналіз показує, що засвоєння чужомовних слів у складі фразеологізмів має свою специфіку: з огляду на експресивно-оцінну функцію народно-розмовної фразеології в складі ДФО збереглися або запозичення із експресивно-оцінною конотацією, або такі, що замінили у складі фразеологізму один із компонентів (брати на конт - брати на зошит (хрестик); тримати пізвму - тримати зло; пустити харамана - напустити туману та ін.), що спричинено потребою створення додаткової експресивності фразеологізму. Як 
Галина Т. Кузь Лексичні запозичення в діалектній фразеології говірок Чернівецьької області...

вважає М. Олійник, «часто фактором посилення експресивності $\epsilon$ невмотивованість для діалектоносіїв значення ФО, наявність компонентів із затемненою семантикою» (Олійник, 2002, с. 6). Саме цим, очевидно, пояснюється той факт, що із запозичень-румунізмів, зафіксованих К. Германом, у складі ДФО Чернівеччини фігурують лише два (бринза, буката).

Що ж до територіального поширення ДФО аналізованої групи, то й тут маємо відзначити відмінності наших висновків із спостереженнями над запозиченою з румунської мови лексикою К. Германа. Діалектолог зазначає, що вони локалізовані нерівномірно: найбільше інтерференція присутня в селах, де українці і румуни проживають в межах одних сіл, і меншою мірою - в населених пунктах, що межують із румунськомовним регіоном, а також тих, що не контактують із останнім (Герман, 2008, сc. 14-15). Переважна частина проаналізованих ДФО, за даними словника Фразеологізми та паремії Чернівеччини, побутує не на територіях/або не лише на територіях спільного проживання українців і румун чи фронтального їх контактування, а власне в районах, територіально віддалених від румунських говірок (32 із 39 ДФО). 19 ДФО поширені також/або лише в районах фронтального контактування українських і румунських говірок (Кельменецький та Сокирянський райони) та на територіях спільного проживання українців та румун (Сторожинецький, Глибоцький, Герцаївський та Новоселицький райони).

Із 39 ДФО у словнику Фразеологізми та паремії Чернівеччини лише три подані із ремаркою застаріле. 14 ДФО зафіксовані у Словнику буковинських говірок (СБГ, 2005), що свідчить про їх активне використання щонайменше в другій половині XX - на початку XXI ст ${ }^{1}$.

\section{Германізми у складі ДФО}

Фіксуємо у складі буковинських ДФО 33 компоненти-запозичення 3 німецької мови безпосередньо чи через посередництво польської/ чеської мов у складі 60 ДФО:

1 Програма-питальник для збирання матеріалів до обласного словника буковинських говірок була розроблена в 1957 році. Протягом 1971-1978 років було видано шість випусків Матеріалів до словника буковинських говірок. 
Галина Т. Кузь Лексичні запозичення в діалектній фразеології говірок Чернівецьької області...

бити блинди. 1. 'байдикувати, ледарювати'. 2. 'пустувати, розважатися'. (ФПЧ, 2017, с. 36). БЛИНДА - 'жебрак, сліпа особа'. Можливо, походить від нім. blind 'сліпий' (ЕСУМ, 1982-2012, т. 1, с. 207);

Гоп иурік, в другий бік! 1. 'вигук, який супроводжує танцювальний рух'. 2. 'вираз незадоволення, здивування несподіваною зміною планів' (ФПЧ, 2017, с. 68). ЦУРІК - вигук, яким повертають коней назад (СБГ, 2005, с. 632); з нім. zurück 'назад';

дати шміру кому. 'насварити, набити, покарати' (ФПЧ, 2017, с. 77). ШМIP - з нім. Schmiere 'мастило'; пор. шмір - мазь, вживана для замочування ткацького шнура (Демський, 1981, с. 218). Очевидно, тут йде мова про побиття таким шнуром;

дати/dicmaти шпіияа (шпіиака). 'дати/отримати копанця' (ФПЧ, 2017, с. 77); брати на шиіи, кого. 'глузувати, насміхатися' (ФПЧ, 2017, c. 45). ШПІЦ - 'загострена передня частина постола, черевика, сандаля' (СБГ, 2005, с. 671); нім. Spitze 'шпиль; гострий кінець, вістря' (ЕСУМ, 1982-2012, т. 6, с. 464); пор. брати на патички 'те саме' (ФПЧ, 2017, с. 45);

i (mа й) фертик. 'і все, і кінець' (ФПЧ, 2017, с. 109). ФЕРТІК (ФЕРТИК) 1. 'готово, кінець'. 2. 'досить, вистачить'. 3. 'кінець, смерть' (СБГ, 2005, с. 587); з нім. fertig 'готовий';

класти зуби на банти. 'голодувати' (ФПЧ, 2017, с. 114). БАНТА - 1) 'перекладина'; 2) 'сідало для курей' (СБГ, 2005, с. 24); $з$ нім. Band 'стрічка; пор. класти зуби на полицю (мисник) 'те саме' (СФУМ, 2003, т. 1, с. 300);

мандер Орися. 'ходити селом без діла' (ФПЧ, 2017, с. 128). МАНДЕР 3 нім. wandern 'блукати, мандрувати'. Мотивоване тим самим образом, що й ходити льонтом, ходити магурами, які ми аналізували вище;

мати seшефт 3 ким. 'мати справи з кимсь, торгувати' (ФПЧ, 2017, с. 130); перебити seшефm (simeф) справу' (ФПЧ, 2017, с. 168); ГЕШЕФТ - запозичення з нім. мови; нім. Geschäft 'справа, торгова угода' (ЕСУМ, 1982-2012, т. 1, с. 503);

мати рuxm, заст. 'мати вигоду' (ФПЧ, 2017, с. 132); не в рихт. 'недовподоби' (СБГ, 2005, с. 456); РИХТА - 'податок, прибуток'; можливо, пов'язане з нім. Recht 'право, закон' (ЕСУМ, 1982-2012, т. 5, c. 85$)$; 
Галина Т. Кузь Лексичні запозичення в діалектній фразеології говірок Чернівецьької області...

мати фрай. ‘бути незалежним у своїх діях’ (ФПЧ, 2017, с. 132). ФРАЙ з нім. frei 'вільний';

на листу катараму, зі сл. сварити, машкарити та ін. 'дуже сильно, останніми словами’ (ФПЧ, 2017, с. 141). ЛИСТИЙ (ЛЕСТИЙ) заст. 'найгірший, останній' (СБГ, 2005, с. 257); 3 нім. letzt 'останній';

пхати (тикати) итири грейцари, заст. Утручатися в чужі справи; утручатися в розмову (ФПЧ, 2017, с. 187). КРЕЙЦЕР - 'розмінна монета з срібла й міді в Німеччині та Австро-Угорщині'; запозичення з німецької мови; свн. Kriuzer 'крейцер; срібний пфеніг' (ЕСУМ, 1982-2012, т. 3, с. 82);

Шлюс, Параню, по коханню, [віддай перстень, бо я сі не женю]! (ФПЧ, 2017, с. 340). ШЛЮС - $з$ нім. Schlus, Schlusse 'все, кінець'.

Поширеним у буковинських пареміях є прикметник файний, фіксуємо його у 21 контекстах, напр.: Як ся файно зачєло, так ся файно й скінчило (ФПЧ, 2017, с. 348); 3 файної тарілки файний і черепок (ФПЧ, 2017, с. 295); Як (єк) дівка файна, то й півка файна (ФПЧ, 2017, с. 345). ФАЙНИЙ - 'гарний; добрий; якісний'; запозичення з пол. мови; пол. fajny 'хороший, гарний'; походить від нім. fein 'тонкий, дрібний, ніжний' (ЕСУМ, 1982-2012, т. 6, сс. 64-65).

Серед ДФО, у яких простежуються зв'язки української та польської фразеології з німецькомовним джерелом, фразеологізми з дієсловом трафбити (від нім. treffen 'влучати'). Воно належить до пласту давніх германізмів: не трафив у свої двері. 'не те робити, не те казати' (ФПЧ, 2017, с. 155); шляк трафив кого. 1. 'загинути, пропасти'. 2. 'турбуватися, нервуватися, страждати'. 3. мед. 'стався інсульт'. 4. виг. 'прокльон' (ФПЧ, 2017, с. 228); ШЛЯК (шляг), пол. szlag (діал. szlak, ślak) є запозиченням 3 нім. Schlag 'удар; параліч' (ЕСУМ, 1982-2012, т. 6, с. 442).

Через польське (деякі, можливо, через чеське) посередництво потрапили в південно-західні говірки лексеми-германізми (встановлюємо це на підставі даних Етимологічного словника української мови):

spic: як свиня в spici, зі сл. розбиратися, розумітися та ін. 'не розбиратися’ (ФПЧ, 2017, с. 259); як миш (пес) до spicy, зі сл. шкіритиси, згруб. 'не до речі посміхатися' (ФПЧ, 2017, с. 249). ГРИС (гріс) - 'грубо змелений овес з ячменем', 'висівки’; запозичено через посередництво польської мови з німецької; нім. Grieß 'манна крупа; грубий пісок; гравій’(ЕСУМ I, 1982-2012, с. 596); 
Галина Т. Кузь Лексичні запозичення в діалектній фразеології говірок Чернівецьької області...

dpim: dpim пряде хто. 'поганий характер'; 'про люту жінку, дівчину' (ФПЧ, 2017, с. 84). ДРІТ (дро́тє) - 'сплетений удвоє мідний дріт, вживаний для гуцульських виробів'; запозичене з німецької мови через польське посередництво; нім. Draht 'дріт' (ЕСУМ II, 1982-2012, c. 131); пор. також дратва 'міцна просмолена або навощена нитка, якою шиють взуття, шкіряні вироби і т. ін' (СУМ II, 1970-1980, c. 408). Очевидно, ДФО пов'язана із уявленням про те, що прядіння міцної нитки потребує особливих фізичних, а відтак і психічних сил;

зияарок: як зияарок (в зияарку). 'точно, злагоджено' (ФПЧ, 2017, с. 243). Для шмарків нима дзигарків. 'жартівлива відповідь дитині на питання «Котра година?» (ФПЧ, 2017, с. 287); ДЗИГАР (дзигарок) - 'годинник'; через посередництво польської мови запозичено з німецької; нім. Seiger 'висок (прилад); годинник' (ЕСУМ II, 1982-2012, c. 59);

кавалєр: ходити на кавалєрку. 'ходити на побачення' (ФПЧ, 2017, с. 219). КАВАЛЕР - 'супутник жінки в товаристві; парубок; мужчина; холостяк'; - запозичене через посередництво пол., нім. та франц. мов з італ.; нім. Kavalier 'вершник', з лат. Caballärius (ЕСУМ II, 1982-2012, с. 334);

кант: на кант, зі сл. класти, давати. 'негайно, одразу' (ФПЧ, 2017, c. 140). КАНТ - 'облямівка, край, ребро'; запозичене з нім. мови (можливо, через польську); нім. Kante - 'край, ребро' (ЕСУМ II, 1982-2012, с. 365). Вживається у контексті вимоги заплатити гроші одразу, невідкладно; покласти їх на стіл (пор., Половинки файні. Гроші на кант, $і$ носи на здоров'ї (СБГ, 2005, с. 186)). Имовірно, має місце метонімічне перенесення з назви 'стіл' на назву його частини;

катран: як катран з плоту, зі сл. пропасти. 1. ‘занепасти'. 2. ‘зникнути безслідно' (ФПЧ, 2017, с. 245). КАТРАН (картан) - 'підтичка з тисненими квітами', 'жіночий фартух; ганчірка'; результат видозміни форми [картун]; нім. Kattun 'ситец' < араб. qutun 'бавовна') (ЕСУМ II, 1982-2012, с. 396);

криси: забити у свою крису. 'робити на свою користь' (ФПЧ, 2017, с. 88). КРИСИ - 'відігнуті краї капелюха, бриля’; очевидно, через пол. посередництво запозичено з нім. (ЕСУМ IV, 1982-2012, с. 94); 
Галина Т. Кузь Лексичні запозичення в діалектній фразеології говірок Чернівецьької області...

льос: iде льос. 'щастить, усе добре складається' (ФПЧ, 2017, с. 104); ЛЬОС - 'жереб, доля, удача'; через посередництво пол. запозичене 3 нім.; пол. los 'доля; призначення'; нім. Los 'те саме' (ЕСУМ III, 1982-2012, с. 348);

маглівниия: як маллівниия, зі сл. дорога. 'нерівна, вся у вибоїнах' (ФПЧ, 2017, с. 248). МАГІВНИЦЯ (маглівниця) - 'рубель; пральна дошка; велика палиця'; через посередництво пол. мови запозичено з нім.; нім. Mange(l) 'качалка для прасування білизни', з гр. mánganon) (ЕСУМ III, 1982-2012, с. 352);

мандабурка: наговорити мандабурки, знев. 'говорити незрозуміло, говорити нісенітниці' (СБГ, 2005, с. 67). МАНДАБУРКА - 'картопля’; пол. mandyburka, яке пов’язане із назвою німецького міста Brandenburg чи Magdeburg (ЕСУМ III, 1982-2012, с. 379). Значення ДФО мотивоване запозиченим компонентом з непрозорою внутрішньою формою;

пляцок: падати пляцком. 1. 'стомитися' 2. 'дуже здивуватися'. 3. ірон. 'виявляти повагу, пошану' (ФПЧ, 2017, с. 61). ПЛЯЦКОМ 'нерухомо' (СБГ, 2005, с. 432); ПЛЯЦОК - 'низької якості корж, перепічка'; очевидно, через польське посередництво запозичено 3 нім. мови; нім. Platz 'тонке тістечко, печиво; пиріг' (ЕСУМ, 1982-2012, т. 4, с. 464);

фіра, дишель: як фіра без дишла (дишля), зі сл. ходити, тинятися, валандатися. 'без цілі' (ФПЧ, 2017, с. 266). ФІРА - ‘фонетичний

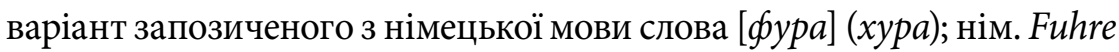
'віз, підвода' (ЕСУМ, 1982-2012, т. 6, с. 102); ДИШЕЛЬ (дишло) 'дишло у рала'; через посередництво пол. мови запозичене з нім.; вн. dīhsel - 'дишло' (ЕСУМ, 1982-2012, т. 2, сс. 80-81). Мотивоване конструкційними особливостями підводи;

фіранка: не шукати фіранок (в печі). 'про зайві клопоти' (ФПЧ, 2017, с. 157); показувати на капелюсі фіранки. 'примхливо поводитися, вередувати' (ФПЧ, 2017, с. 176); як сраці фіранки, зі сл. пасує, личить, ірон. 'не личить' (ФПЧ, 2017, с. 262). ФІРАНКА - 'занавіска на вікні; запозичення з нім. мови (можливо, через посередництво пол.; пол. firanka); нім. Vorhang 'завіса на вікні' (ЕСУМ, 1982-2012, т. 6, сc. 102-103); 
Галина Т. Кузь Лексичні запозичення в діалектній фразеології говірок Чернівецьької області...

и,вя (и,вик): иявя $y$ труну. 'робити щось, що призведе до знищення кого-небудь' (ФПЧ, 2017, с. 224); Ти йому про ивики, а він тобі про свині дикі (ФПЧ, 2017, с. 330). ЦВИК - запозичене з нім. мови через посередництво пол.; нім. Zweck - ціль, Zwecke - цвях (ЕСУМ, 1982-2012, т. 6, c. 233);

шанець: від шанця до шания, зі сл. іти та ін. 'нерівно (іти), бути п’яним' (ФПЧ, 2017, с. 58). ШАНЕЦЬ (шанц) - 'земляне укріплення у вигляді рову з насипом'; запозичене (через пол. посередництво) 3 нім. мови; нім. Schanze 'окоп, шанець, укріплення' (ЕСУМ, 1982-2012, т. 6, с. 376);

шток: як шток. 'дуже п’яний' (ФПЧ, 2017, с. 268). ШТОК - 'металевий циліндричний стрижень морського якоря'; запозичення з німецької мови (можливо, через пол. чи чес.); нім. Stock 'палиця'; пол. sztok 'колода, на яку спирається ковадло' (ЕСУМ, 1982-2012, т. 6, с. 478);

шуфля: як шуфляя. 'дуже п’яний' (ФПЧ, 2017, с. 268). ШУФЛЯ (шуфель) - 'совок, лопата'; запозичене з нім. мови (можливо, через пол. посередництво); нім. Schaufel 'совкова лопата' (ЕСУМ, 1982-2012, т. 6, с. 497).

Н. Нечаєва на підставі грунтовного аналізу Словника буковинських говірок (2005) констатує наявність 156 запозичень-діалектизмів, що функціонують в буковинських, частина й у суміжних говірках (Нечаєва, 2014, с. 99). Відзначимо, що відносно невелика частина з них (spuc, иурік, шпіи, шмір, катран, фертик, банта, кант, листий, пляцком, мандабурка, трафити) є компонентами ДФО.

К. Герман наводить 34 германізми зі сфери військової лексики та 35 назв побутових, відомих на Буковині до середини ХХ ст., однак лише 8 із 35 побутовізмів, як вважає діалектолог, відомі до цього часу (Герман, 2008). У нашому матеріалі з цього переліку фігурують лише 2 лексеми (фертик, рихт). Значне зменшення кількості германізмів у мовленні буковинців підтверджує О. Сеник: «У часовому вимірі [...] кількість запозичень із німецьким етимоном в буковинському діалекті української мови зменшується» (Сеник, 2014).

Як показує аналіз ДФО із компонентами-германізмами, найбільше таких лексем $є$ побутовими назвами (банта, sрuc, мандабурка, біранка, дзизарок, маглівниия, катран, криси, фіра, шмір, шпіи, шуфля) або назвами, що стосуються професійної діяльності (рuхm, sешебт, иурік). Для 
Галина Т. Кузь Лексичні запозичення в діалектній фразеології говірок Чернівецьької області...

компонентів німецького походження в складі ДФО властива функція надавати додаткової іронічної чи емоційно-оцінної конотації (як свиня в spici (розбиратися); не шукати фіранок (в печі)). Подібну функцію виконують компоненти-германізми, які виступають регіональним варіантом українського компонента (бити блинди бити байдики; показувати на капелюсі фіранки - показувати мухи; пхати (тикати) итири грейцари - пхати своїх п'ять копійок; як шток - як чіп).

\section{Полонізми у складі ДФО}

Українсько-польські мовні контакти відобразилися у компонентному складі 21 ДФО, в якому виступають 13 компонентів-полонізмів чи таких, що потрапили в буковинську говірку через посередництво польської мови (42 ДФО із 19 компонентами-полонізмами німецького походження ми розглядали у попередньому розділі):

заводити бештефранти, заст. 'упроваджувати нові порядки' (ФПЧ, 2017, с. 89); БЕШТЕФРАНТИ - $з$ пол. besztefranty 'жарти, розваги'; можливо, від пол. besztać 'Ганити, лаяти' та нім. Freund найкращий приятель);

дямба (sємба) як воротило у кого. 'хтось пащекуватий' (ФПЧ, 2017, с. 85); дати (врізати, заїхати) в sємбу, згруб. 'ударити' (ФПЧ, 2017, с. 74). ДЯМБА (гємба) - $з$ пол. gęba розм. 'рот';

зводитися на ніч. 'втрачати свою якість, властивості' (ФПЧ, 2017, с. 98); НІЦ - з пол. піс 'нічого, ніщо';

наробити герезіï, заст. 'наробити клопоту, неприємностей' (ФПЧ, 2017, с. 143). ГЕРЕЗА (гирезія) - 'лихо, сварка, розбрат'; запозичення з пол. мови; пол. herezja - 'скандал, бешкет' (ЕСУМ, 1982-2012, т. 1, с. 499);

показувати фохи. 'примхливо поводитися, вередувати' (ФПЧ, 2017, c. 176). ФОХИ - з пол. fochy 'капризи, забаганки’;

пускати блахмана (в очі). 'напускати туману, вводити в оману' (ФПЧ, 2017, с. 185). БЛАХМАН - 'туман перед очима'; запозичення з пол. мови; пол. blachman - 'більмо, полуда' (ЕСУМ, 1982-2012, т. 1, с. 206);

бити бомки. 1. 'байдикувати, ледарювати'. 2. 'пустувати, розважатися' (ФПЧ, 2017, с. 36); гнути (уповідати) бомки, знев. 'розмовляти ні про 
Галина Т. Кузь Лексичні запозичення в діалектній фразеології говірок Чернівецьької області...

що, говорити невпопад' (ФПЧ, 2017, с. 66); БОМОК - 'гедзь'; запозичення 3 пол. мови; пол. $b a q k$ - 'овід, гедзь' (ЕСУМ, 1982-2012, т. 1, с. 228);

брати (братися, взяти) за барки кого. 1. 'вхопити(ся) за поли'. (СБГ, 2005, с. 25). 2. 'пориватися до бійки'. (ФПЧ, 2017, с. 51). БАРКИ 'плечі; верхня частина спини'; запозичення з пол. мови; пол. bark 'частина руки від плеча до ліктя'(ЕСУМ, 1982-2012, т. 1, с. 144);

ладувати бебехи. 'збирати речі в дорогу' (ФПЧ, 2017, с. 123); повні бебехи, зі сл. набрати, дати. 'багато; повні торби' (ФПЧ, 2017, с. 174); розкласти (свої) бебехи. 'замешкати де-небудь, розташуватися'. (ФПЧ, 2017, с. 193). БЕБЕХИ - 1) нутрощі; 2) клунки, пожитки, скарб (СБГ, 2005, с. 27); БЕБЕХ - 'велике черево; перина, подушки; нутрощі'; пол. bebechy 'нутрощі; злиденна постіль, пожитки' (ЕСУМ, 1982-2012, т. 1, с. 158);

робити sвалт. 'кричати, лементувати'. Заг. (ФПЧ, 2017, с. 188). ГВАЛТ 'сильний крик, галас'; запозичення з пол.; пол. gwatt 'насильство' (ЕСУМ, 1982-2012, т. 1, с. 485);

Усе мож зробити, лиш сподні через голову не мож убрати (ФПЧ, 2017, с. 333); Хочеш срати, сподні скинеш (ФПЧ, 2017, с. 335); Хто рано встав, той сподні вбрав (ФПЧ, 2017, с. 336). СПОДНІ - $з$ пол. spodnie 'штани, брюки' (WSJP, 2007);

gisлi-міsлi. 'витівки, штуки, хитрощі для досягнення чого-небудь' (ФПЧ, 2017, с. 217); фisлі в голові (на умі) у кого. 'думати про залицяння, жарти, пустощі' (ФПЧ, 2017, с. 217); вистроювати (робитu) фis $і$. 'удаватися до жартів, щоб насмішити або обдурити когось' (ФПЧ, 2017, с. 54). ФІГЛІ - запозичення з польської мови; пол. figiel, figle-migle ‘фіглі' (ЕСУМ, 1982-2012, т. 6, с. 95).

Через польську мову могли потрапляти до української запозичення 3 інших мов, наприклад з італійської: від фоси до фоси, зі сл. іти та ін. 'нерівно (іти), бути п'яним'. ФОСА (шанець) - 'канава, рів, рівчак' (СБГ, 2005, c. 598). ФОСА - 'канава, рів'; через посередництво пол. запозичене з італійської: пол. fosa 'канава, рів'; іт. fossa < походить від лат. fossa (ЕСУМ VI, 1982-2012, с. 123).

Як бачимо, як і в попередніх групах, маємо справу із варіативними запозиченими компонентами (дати в гємбу - дати в писок; пускати блахмана - пускати туману; наробити герезії - наробити клопоту 
Галина Т. Кузь Лексичні запозичення в діалектній фразеології говірок Чернівецьької області...

та ін.). У цьому випадку запозичений компонент створює експресивну конотацію ДФО. Фіксуємо також вживання лексем-полонізмів з оцінною конотацією (фіглі, герезія, бебехи).

Чимала кількість ДФО (27), у яких простежується зв'язок з польською мовою утворилася шляхом калькування або напівкалькування, а також запозичення фразеологізму. До таких Л. Ткач, відносить наступні ДФО: богу духа винен (ФПЧ, 2017, с. 39); в живі очі, зі сл. говорити, сказати та ін. (ФПЧ, 2017, с. 51); вивести в поле, заст. (ФПЧ, 2017, с. 51); за песю иіну/ за песі гроші, зі сл. робити, продати (ФПЧ, 2017, с. 95); за солені гроші, заст. (ФПЧ, 2017, с. 96); завертати голову кому. (ФПЧ, 2017, с. 89); запрятати голову, заст. (ФПЧ, 2017, с. 95); зійти на пси (ФПЧ, 2017, с. 99); мати віз і перевіз (ФПЧ, 2017, с. 129); на лік, зі сл. не мати, не знайти та ін., заст. (ФПЧ, 2017, с. 141); на серйо, заст. зі сл. брати, забратися, думати, писати (ФПЧ, 2017, с. 143); ні на волос, зі сл. не попускати, не відступати та ін. (ФПЧ, 2017, сс. 159-160); почати з іншої бочки (ФПЧ, 2017, с. 179); у чотири (итири) оці, зі сл. дивитися. (ФПЧ, 2017, с. 216); як батіг тріснув (ФПЧ, 2017, с. 233); як борш, зі сл. дешевий. (ФПЧ, 2017, с. 235); як віл до карети, зі сл. пасує, підходить, здібний. (ФПЧ, 2017, с. 235); як око в голові, зі сл. берегти, оберігати та ін., когось, щось (ФПЧ, 2017, с. 253) (Ткач, 2007, сc. 94-106). Частина наведених ДФО вже вийшли з ужитку і зафіксовані в аналізованому нами словнику з ремаркою застаріле.

До групи кальок або напівкальок віднесемо також ДФО:

зайти в тяж. 'завагітніти' (ФПЧ, 2017, с. 92); пор. zajść w ciążę 'zostać zapłodnioną; spodziewać się dziecka' (SFJP, 1967, т. 2, c. 721);

до вибору й до кольору. 'великий вибір, різноманіття' (ФПЧ, 2017, c. 82); пор., pot., do wyboru, do koloru 'bardzo dużo i można wybierać według upodobania’ (WSJP, 2007);

мати до чиніння з ким, заст. 'мати з кимось спільну справу, наслідки якої є неприємними, небажаними для однієї із сторін' (ФПЧ, 2017, c. 130); пор. mieć z kim do czynienia: 1. 'zawierać znajomość, nawiązywać stosunki'; 2. 'narazić się komu'; 'być zmuszonym rozprawić się z kim’ (SFJP, 1967, т. 1, с. 159). Як бачимо, в українській мові значення фразеологізму зазнало семантичного звуження: фіксуємо в буковинських говірках тільки друге значення;

мати нервічу. ‘бути нервово хворим' (ФПЧ, 2017, с. 132); пор., nerwica, n. serca, żoładka (SFJP, 1967, т. 1, c. 494); 
Галина Т. Кузь Лексичні запозичення в діалектній фразеології говірок Чернівецьької області...

мати обачінє (обачіні), заст. 'бути уважним, людяним' (ФПЧ, 2017, c. 132); ОБАЧІНЄ - повага (СБГ, 2005, с. 343); пор., obaczyć przestarz. 'dzis', reg. Do obaczenia 'do ponowego zobaczenia się, do widzenia' (SFJP, 1967, т. 1, с. 523);

не до віри, заст. 'не віриться' (ФПЧ, 2017, с. 149); пор., nie do wiary; rzecz nie do wiary 'trudno uwierzyć'; '(co jest) nieprawdopodobne, nieoczekiwane, zaskakujące' (SFJP, 1967, т. 2, c. 536);

не до оповідання. 'не могти розповісти, переказати' (ФПЧ, 2017, с. 149); пор., mieć co do powiedzenia 'móc coś o czym powiedzieć, nadmieniać, że się o kim (czym) coś wie (zwykle ujemnego), ale nie wypada tego wyjawiać' (SFJP, 1967, т. 1, c. 438);

тягнути льос. 'витягати картку (вид ворожіння)' (ФПЧ, 2017, с. 213); пор., ciagnać, rzucać losy o co 'losować, rozstrzygać co przez losowanie' (SFJP, 1967, т. 1, с. 394).

Впадає в око велика кількість ДФО, що з'явилися в буковинських говірках внаслідок повного запозичення або напівкалькування з польської мови. Очевидно, це пов'язано із близькою спорідненістю польської та української мов: для носіїв говірки запозичувати цілі звороти з мови відносно зрозумілої $є$ нескладним, тоді як подібним чином запозичувати румунські, німецькі чи гебрайські звороти було складно. Проте велика частина таких запозичених з польської мови фразеологізмів на сьогодні уже сприймаються як застарілі, що, очевидно, спричинене відсутністю безпосереднього контакту з польськомовним середовищем.

\section{Гебраїзми/їдишизми у складі ДФО}

Наявні в компонентному складі ДФО Чернівеччини нечисленні запозичення-гебраїзми (9 ДФО):

великий пуреи (пурии). 'людина, що безпідставно претендує на головну роль, центральне місце' (ФПЧ, 2017, с. 50). ПУРИЦ - 'зарозумілий парубок, чоловік'; запозичення з мови їдиш; пор. ід. рuric 'великий пан'(ЕСУМ, 1982-2012, т. 4, с. 637);

imu/nimu до кагалу (кагану). 'іти спільно виконувати сільськогосподарські чи будівельні роботи не за гроші, а за пригощання та можливість 
Галина Т. Кузь Лексичні запозичення в діалектній фразеології говірок Чернівецьької області...

відробити навзаєм’ (ФПЧ, 2017, с. 107). КАГАЛ - ‘єврейська община, юрба'; запозичення з гебр. мови; гебр. kāhāl 'зібрання старшин, община' (ЕСУМ, 1982-2012, т. 2, с. 336);

мати иурес. 'мати непорозуміння, проблеми з ким-небудь; неприємності' (ФПЧ, 2017, с. 133). ЦУРЕС - 'нещастя'; запозичення з івриту через їдиш;

робити кіпіш. 1. 'кричати, лементувати'. 2. 'змушувати когось діяти' (ФПЧ, 2017, с. 190). КІПІШ - 'бійка, сварка, колотнеча, метушня';

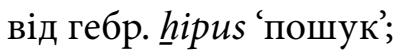

робити з себе гакмана. 'Удавати, прикидатися' (ФПЧ, 2017, с. 190). ГАКМАН - єврейське прізвище;

як гамана, зі сл. бити, побити. 'дуже сильно' (ФПЧ, 2017, с. 237). ГАМАН - 'особа, яку під час свята Пурім євреї використовують як об’єкт глузування і жорстокого поводження'; походить від гебр. На̄mān - ім'я біблійного перського сановника, ворога євреїв (ЕСУМ, 1982-2012, т. 1, с. 464);

як Беркові штани, зі сл. розумний. 'дурень' (ФПЧ, 2017, с. 233);

як Мошкові гатки, зі сл. гарна, красна та ін. 'негарна' (ФПЧ, 2017, с. 250);

як Соломонів патинок, зі сл. розумний, учений. 'нерозумний' (ФПЧ, 2017, c. 261).

Компоненти-гебраїзми/їдишизми у складі ДФО додають експресивної конотації, порівн.: великий пуреи - великий пан; бити як гамана - як сидорову козу; як глуху зозулю; мати иурес - мати клопіт; робити кіпіш - робити колот. Запозичені особові назви (імена чи, рідше, прізвища), характерні для представників єврейського етносу, в контексті ДФО виконують особливу ідентифікаційну функцію, а також створюють іронічне забарвлення.

\section{Гунгаризми у складі ДФО}

Нами зафіксовано кілька запозичень з угорської мови у складі 9 ДФО Чернівеччини:

зазирати в пугар (nогар). 'зловживати алкогольними напоями' (ФПЧ, 2017, с. 91); погарі не просихают у кого. 'про зловживання алкогольними напоями' (ФПЧ, 2017, с. 175). ПОГАР - 'кубок, келих’; 
Галина Т. Кузь Лексичні запозичення в діалектній фразеології говірок Чернівецьької області...

запозичене з уг. мови (можливо, через словацьке посередництво); уг. pohár - 'склянка, чарка, кухоль' (ЕСУМ, 1982-2012, т. 4, с. 473);

хосен як сліпій бабі з кросен. 'про щось мало корисне, невигідне' (ФПЧ, 2017, с. 220). ХОСЕН - 'користь'; запозичення з уг. мови; уг. haszon - 'користь, вигода' (ЕСУМ, 1982-2012, т. 6, с. 204);

дістати паприки. 'дістати прочухана, зазнати покарання' (ФПЧ, 2017, c. 81). ПАПРИКА - 'перець'; запозичення з уг. мови; уг. paprika 'перець' (ЕСУМ, 1982-2012, т. 4, с. 285);

Смійся, дурню, дараба пливе (йде). // Смійся, Якове, смійся: горі дараба йде. Про безпричинний сміх (ФПЧ, 2017, с. 327). ДАРАБА - 'пліт із сплавного дерева'; запозичення з угорської мови; з уг. darab 'шматок, штука' (ЕСУМ, 1982-2012, т. 2, с. 12);

Газда без коня - як біра без колеса (ФПЧ, 2017, с. 284); Газда з хати миші в данеи (ФПЧ, 2017, с. 284); Де sазда не ходит, там хліб ся не родит (ФПЧ, 2017, с. 284); ГАЗДА - 'господар'; запозичення з уг.; уг. gazda 'господар' (ЕСУМ, 1982-2012, т. 1, сc. 450-451).

Характерною особливістю ДФО, як показує аналіз, є яскраво виражена емоційність, тісно пов’язана з їх експресивністю. Одним із способів творення такої експресивності $€$ введення у фразеологізм запозичених елементів.

Наше дослідження виявило значно більшу стабільність запозичень на фразеологічному рівні порівняно із лексичним. Якщо в лексиці буковинських говірок дослідники (К. Герман, О. Сеник) спостерігають відносно швидку втрату, наприклад, германізмів чи полонізмів, то фразеологізмів, зафіксованих писемними джерелами початку XX ст., які в аналізованому словнику подані із ремаркою застаріле, не так багато (3 - з румунізмами; 2 - 3 германізмами; 2 - 3 полонізмами; 8 ДФО запозичених чи скалькованих з польської мови). Швидкий вихід з ужитку кальок чи напівкальок з польської мови спричинений майже цілковитою втратою безпосереднього контакту з носіями польської мови на Чернівеччині.

Отже, міжмовні зв'язки відображаються на фразеологічному рівні: а) в компонентному складі фразеологічних одиниць; б) у наявності скалькованих чи запозичених фразеологізмів; в) в існуванні міжмовних (інтернаціональних) моделей (у нашій розвідці ми це питання не розглядали). 
Галина Т. Кузь Лексичні запозичення в діалектній фразеології говірок Чернівецьької області...

\section{Скорочення}

ДФО - діалектна фразеологічна одиниця

ЕСУМ - Етимологічний словник української мови (Мельничук, 1982-2012).

КСЖЛ - Короткий словник жаргонної лексики української мови (Ставицька, 2003).

РPС - Румьно-русский словар (Поповскій, 1922).

РУС - Румунсько-український словник (Dicţionar român-ucrainean, 1996).

СБГ - Словник буковинських говірок (Гуйванюк, 2005).

СУМ - Словник украӥнськой мови (Білодід, 1970-1980).

СФУМ - Словник фразеологізмів украӥнської мови (Білоноженко, 2003).

ФПЧ - Фразеологізми та паремї Чернівеччини (Кузь, Руснак, Скаб, \& Томусяк, 2017).

ФСУМ - Фразеологічний словник украӥнської мови (Білоноженко, 1993).

SFJP - Słownik frazeologiczny języka polskiego (Skorupka, 1967).

WSJP - Wielki słownik języka polskiego PAN (Żmigrodzki, 2007).

\section{Бібліографія}

Герман, К. (2010). Українсько-романські міждіалектні взаємини в говірках Буковини. In П. Гриценко \& Н. Хобзей (Eds.), Діалектологічні студіi: Запозичення та інтерференція (рp. 36-44). Львів: Ін-т українознавства ім. І. Крип'якевича.

Герман, К.Ф. (2008). Розвиток лексики українських говірок Буковини в ХХ столітті. Науковий вісник Чернівецького університету, 428-429, 9-16.

Головач, Н. М. (2012). Лексичні румунізми в украйнсвкій мові на діалектному та літературно-нормативному рівнях (Автореф. дис. ... канд. філол. наук). Чернів. нац. ун-т ім. Юрія Федьковича, Чернівці.

Демський, М. (1981). Українські фраземи і особливості їх творення. Львів: Просвіта.

Дехтярьова, О.В. (2013). Лексичні запозичення в компонентному складі діалектних фразеологізмів (на матеріалі художніх творів західноукраїнських письменників кінця XIX - початку XX). In Філологічні студіi: Збірник наукових пращь (pp. 23-29). Кривий Ріг.

Лопушанський, В., \& Пиц, Т. (2011). Німецькомовні лексичні запозччення у південнозахідних говорах України. Дрогобич: Посвіт.

Нечаєва, Н. (2014). Запозичення з німецької мови в буковинських говірках. Науковий вісник Східноєвропейського національного університету імені Лесі Украйнки: Серія «Філологічні науки: Мовознавство», 2014(2), 98-102. 
Галина Т. Кузь Лексичні запозичення в діалектній фразеології говірок Чернівецьької області...

Олійник, М. Я. (2002). Фразеологія гуиульських говірок (Автореф. дис. ...канд. філол. наук). Львівський національний ун-т ім. Івана Франка, Львів.

Пиц, Т. Б. (2011). Посередництво німецької мови у запозиченні іншомовних лексем південно-західними говорами української мови. Сучасні дослідження з іноземної філологіi, 9, 374-379.

Сеник, Г. І. (2014). Українсько-німецькі мовні контакти на Буковині (Дисертація канд. філол. наук). Нац. пед. ун-т ім. М. П. Драгоманова, Київ.

Ткач, Л. (2007). Українська літературна мова на Буковині в кінці ХІХ - на початку ХХ століття: Частина 3. Буковинська фразеологія у міжмовних зв'язках та в загальноукраїнському контексті. Чернівці: Книги-XXI.

\section{Словники}

Білодід, І. К. (Еd.). (1970-1980). Словник украӥнської мови: В 11 mm. [СУМ]. Київ: Наукова думка.

Білоноженко, В. М. (Ed.). (1993). Фразеологічний словник украӥнської мови [ФСУМ] (Vols. 1-2). Київ: Наукова думка.

Білоноженко, В. М. (Еd.). (2003). Словник фразеологізмів української мови [СФУМ]. Київ: Наукова думка.

Гуйванюк, Н. В. (Ed.). (2005). Словник буковинських говірок [СБГ]. Чернівці: Рута.

Кузь, Г., Руснак, Н., Скаб, М., \& Томусяк, Л. (Сотр.). (2017). Фразеологізми та паремії Чернівеччини: Матеріали до словника. Чернівці: Рута.

Мельничук, О.С. (Еd.). (1982-2012). Етимологічний словник українськоӥ мови [ЕСУМ] (Vols. 1-7). Київ: Наукова думка.

Поповскій, Н. (Сотр.). (1922). Румыно-русский словар [РРС]. Кишиневъ: Книгоиздательство Т. Д. “ШЕХТЕРЬ и Сья”.

Ставицька, Л. О. (2003). Короткий словник жарлонної лексики української мови [КСЖЛ]. Київ: Критика.

Dicţionar român-ucrainean [Румунсько-украӥнський словник] [РУС]. (1996). Bucarest: Editura didactică și pedagogică.

Skorupka, S. (1967). Słownik frazeologiczny języka polskiego [SFJP] (Vols. 1-2). Warszawa: Wiedza Powszechna.

Żmigrodzki, P. (Ed.). (2007). Wielki słownik języka polskiego PAN [WSJP]. Kraków: Instytut Języka Polskiego PAN. Retrieved from http://www.wsjp.pl 
Галина Т. Кузь Лексичні запозичення в діалектній фразеології говірок Чернівецьької області...

\section{Bibliography (Transliteration)}

Dekhtiar'ova, O. V. (2013). Leksychni zapozychennia v komponentnomu skladi dialektnykh frazeolohizmiv (na materiali khudozhnikh tvoriv zakhidnoukraïns'kykh pys'mennykiv kintsia XIX - pochatku XX). In Filolohichni studii: Zbirnyk naukovykh prats' (pp. 23-29). Kryvyı̌ Rih.

Dems'kyı̆, M. (1981). Ukraïns'ki frazemy i osoblyvosti ïkh tvorennia. L'viv: Prosvita.

Herman, K. (2010). Ukraïns'ko-romans'ki mizhdialektni vzaiemyny v hovirkakh Bukovyny. In P. Hrytsenko \& N. Khobzeĭ (Eds.), Dialektolohichni studiï: Zapozychennia ta interferentsiia (pp. 36-44). L'viv: In-t ukraïnoznavstva im I. Kryp'iakevycha.

Herman, K. F. (2008). Rozvytok leksyky ukraïns'kykh hovirok Bukovyny v XX stolitti. Naukovyı visnyk Chernivets'koho universytetu, 428-429, 9-16.

Holovach, N. M. (2012). Leksychni rumunizmy v ukraïns'kiŭ movi na dialektnomu ta literaturnonormatyvnomu rivniakh (Summary of unpublished doctoral dissertation). Cherniv. nats. un-t im. Iuriia Fed'kovycha, Chernivtsi.

Lopushans'ky̆̌, V., \& Pyts, T. (2011). Nimets'komovni leksychni zapozychennia u pivdenno-zakhidnykh hovorakh Ukraïny. Drohobych: Posvit.

Nechaieva, N. (2014). Zapozychennia z nimets'koï movy v bukovyns'kykh hovirkakh. Naukovyı̆ visnyk Skhidnoievrope ̌s' koho natsional'noho universytetu imeni Lesi Ukrä̈nk: Seriia "Filolohichni nauky: Movoznavstvo", 2014(2), 98-102.

Olin̆nyk, M. I. (2002). Frazeolohiia hutsul's'kykh hovirok (Summary of unpublished doctoral dissertation). L'vivs'kyĭ natsional'nyı̆ un-t im. Ivana Franka, L'viv.

Pyts, T. B. (2011). Poserednytstvo nimets'koï movy u zapozychenni inshomovnykh leksem pivdenno-zakhidnymy hovoramy ukraïns'koï movy. Suchasni doslidzhennia z inozemnoï filolohii, 9, 374-379.

Senyk, H. I. (2014). Ukraïns'ko-nimets'ki movni kontakty na Bukovyni (Unpublished doctoral dissertation). Nats. ped. un-t im. M. P. Drahomanova, Kyïv.

Tkach, L. (2007). Ukraïns'ka literaturna mova na Bukovyni v kintsi XIX - na pochatku XX stolittia: Chastyna 3. Bukovyns'ka frazeolohiia u mizhmovnykh zv'iazkakh ta $v$ zahal'noukraïns'komu konteksti. Chernivtsi: Knyhy-XXI.

\section{Dictionaries}

Bilodid, I. K. (Ed.). (1970-1980). Slovnyk ukraïns'koï movy: V 11 tt. [SUM]. Kyïv: Naukova dumka.

Bilonozhenko, V. M. (Ed.). (1993). Frazeolohichnyı̆ slovnyk ukraïns'koï movy [FSUM] (Vols. 1-2). Kyïv: Naukova dumka.

Bilonozhenko, V. M. (Ed.). (2003). Slovnyk frazeolohizmiv ukraïns'koï movy [SFUM]. Kyïv: Naukova dumka.

Dicţionar român-ucrainean [Rumuns'ko-ukraïns'kyĭ slovnyk] [RUS]. (1996). Bucarest: Editura didactică și pedagogică. 
Галина Т. Кузь Лексичні запозичення в діалектній фразеології говірок Чернівецьької області...

Hǔrvaniuk, N. V. (Ed.). (2005). Slovnyk bukovyns'kykh hovirok [SBH]. Chernivtsi: Ruta.

Kuz', H., Rusnak, N., Skab, M., \& Tomusiak, L. (Comp.). (2017). Frazeolohizmy ta paremii Chernivechchyny: Materialy do slovnyka. Chernivtsi: Ruta.

Mel'nychuk, O. S. (Ed.). (1982-2012). Etymolohichnyı̆ slovnyk ukraïns'koï movy [ESUM] (Vols. 1-7). Kyïv: Naukova dumka.

Popovskiŭ, N. (Comp.). (1922). Rumyno-russkiu slovar [RRS]. Kishinev: Knigoizdatel'stvo T. D. "SHEKhTER i S'ia".

Skorupka, S. (1967). Słownik frazeologiczny języka polskiego [SFJP] (Vols. 1-2). Warszawa: Wiedza Powszechna.

Stavyts'ka, L. O. (2003). Korotkyi slovnyk zhargonnoï leksyky ukrä̈ns'koï movy [KSZHL]. Kyïv: Krytyka.

Żmigrodzki, P. (Ed.). (2007). Wielki słownik języka polskiego PAN [WSJP]. Kraków: Instytut Języka Polskiego PAN. Retrieved from http://www.wsjp.pl

\section{Lexical Borrowings in Dialectal Phraseology of the Chernivtsi Region: The Diachronic Aspect}

\section{Summary}

This article is devoted to the analysis of dialectal phraseological units with foreign components (Romanian, German, Polish, Hebrew, Hungarian) recorded in the dictionary entitled "Phraseologisms and Paroemias of the Chernivtsi Region" (Фразеологізми та паремії Чернівеччини, 2017) from the point of view of their number, presence in modern local dialect and membership in certain semantic groups. It was established that borrowed elements referring to household items and those that function as regional synonyms of Ukrainian components in the structure of dialectal phraseological units are the most frequently used ones. The most frequent elements in the analysed linguistic material are groups of words borrowed from Romanian, German and Polish. The study material indicates the absence of complete correlation in the dynamics of borrowings on the lexical and phraseological levels: in most cases the componential composition of popular colloquial phraseology is subordinate to their emotional-evaluative and expressive functions. 


\title{
Zapożyczenia leksykalne w frazeologii dialektów obwodu czerniowieckiego: aspekt diachroniczny
}

\author{
Streszczenie
}

Artykuł poświęcony jest analizie frazeologicznych jednostek dialektalnych z komponentami obcojęzycznymi (rumuńskimi, niemieckimi, polskimi, hebrajskimi, węgierskimi) zarejestrowanych w Słowniku frazeologizmów i paremii obwodu czerniowieckiego (Фразеологізми та паремії Чернівеччини, 2017) z punktu widzenia ich frekwencji we współczesnym dialekcie oraz przynależności do pewnych grup semantycznych. Ustalono, że najczęściej we frazeologizmach dialektalnych zachowują się zapożyczone nazwy przedmiotów gospodarstwa domowego, jak również te, które są regionalnymi synonimami części składowych ukraińskich frazeologizmów. Najczęściej spotykanymi elementami analizowanego materiału językowego są grupy słów zapożyczonych z języka rumuńskiego, niemieckiego i polskiego. Zbadane materiały wskazują na brak pełnej korelacji w dynamice zapożyczania na poziomie leksykalnym i frazeologicznym: komponenty potocznej frazeologii ludowej zwykle są podporządkowane ich funkcjom emocjonalno-ewaluacyjnym i ekspresyjnym.

Keywords: dialectal phraseology; borrowings; linguistic interference; Romanian borrowings; German borrowings; Polish borrowings; Hebrew borrowings; Hungarian borrowings

Słowa kluczowe: frazeologia dialektalna; zapożyczenia; interferencja językowa; zapożyczenia rumuńskie; zapożyczenia niemieckie; zapożyczenia polskie; zapożyczenia hebrajskie; zapożyczenia węgierskie

\footnotetext{
Halyna T. Kuz, Yuriy Fedkovych Chernivtsi National University, Chernivtsi ORCID: https://orcid.org/0000-0003-0075-4657

Correspondence: kuz.halyna.cv@gmail.com

The preparation of this article was financed by the author.

Competing interests: The author declares that she has no competing interests.
} 